(C) 2009 The Journal of Medicine and Philosophy 34(5): 470-486.

\title{
METAPHYSICAL AND ETHICAL PERSPECTIVES ON CREATING ANIMAL-HUMAN CHIMERAS ${ }^{1}$
}

\author{
Jason T. Eberl \\ Rebecca A. Ballard \\ Indiana University-Purdue University Indianapolis, Indianapolis, IN, USA
}

ABSTRACT

This paper addresses several questions related to the nature, production, and use of animal-human chimeras. At the heart of the issue is whether certain types of animal-human chimeras should be brought into existence, and, if they are, how we should treat such creatures. In our current research environment we recognize a dichotomy between research involving nonhuman animal subjects and research involving human subjects, and the classification of a research protocol into one of these categories will trigger different ethical standards as to the moral permissibility of the research in question. Are animalhuman chimeras entitled to the more restrictive and protective ethical standards applied to human research subjects? We elucidate an Aristotelian-Thomistic metaphysical framework in which to argue how such chimeras ought to be defined ontologically. We then examine when the creation of, and experimentation upon, certain types of animal-human chimeras may be morally permissible.

Keywords: chimera, hybrid, Thomas Aquinas, personhood, potentiality

\section{INTRODUCTION}

When Stuart Newman and Jeremy Rifkin filed Patent Application No. 08/993,563 in 1998, very few people in the scientific, legal, and philosophical communities had

\footnotetext{
${ }^{1}$ Versions of this paper were presented at colloquia sponsored by the Indiana University Center for Bioethics and the Poynter Center at Indiana University, Bloomington. We are grateful to our colleagues at both centers for valuable feedback, as well as to our anonymous referees for their helpful comments.
} 
contemplated the production of a human-nonhuman chimera outside of mythology and science-fiction. But with the successful creation of the first embryonic chimeras in 1984, produced from goat and sheep embryos and called "Geeps," Newman and Rifkin felt it was only a matter of time before the creation of chimeras involving human embryos was attempted. They filed their patent application in order to bring to the world's attention the possibility of creating human-nonhuman chimeras, as well as to establish a legal obstacle to such entities being patentable (Donnelly 2005). Their goals were accomplished when the United States Patent and Trademark Office denied the application, stating that the invention described in the patent "embraces a human being," thereby triggering the United States Constitution's $13^{\text {th }}$ amendment abolishing slavery (Rabin 2006).

As the national debate concerning the creation of chimeras begins to take shape, there are some elementary questions that need to be addressed. At the heart of the issue is whether certain types of human-nonhuman chimeras should be brought into existence, and, if they are, how we should treat such creatures. In our current research environment we recognize a dichotomy between research involving nonhuman animal subjects and research involving human subjects, and the classification of a research protocol into one of these categories will trigger different ethical standards as to the moral permissibility of the research in question. Typically this poses no problems. Aside from standard concerns regarding how nonhuman animals ought to be treated, a mouse is a mouse and a human being is a human being, and ethical standards are applied accordingly. ${ }^{2}$ However, animalhuman $[\mathrm{a}-\mathrm{h}]$ chimeras may be entitled to the more restrictive and protective ethical standards applied to human research subjects. In this paper, we will elucidate a

\footnotetext{
${ }^{2}$ For a serious challenge to the current paradigm of how ethical standards are applied to nonhuman animals, particularly Great Apes, in the context of research using chimeras created from such animals, see DeGrazia 2007.
} 
metaphysical framework in which to argue how a-h chimeras ought to be defined ontologically. Based on the conclusion drawn, we will then examine when the creation of, and experimentation upon, certain types of a-h chimeras may be morally permissible.

\section{What IS A Chimera AND Why Would We CREATE OnE? ${ }^{3}$}

Broadly speaking, the term "chimera" refers to a biological entity composed of genetic material from members of two distinct species. Although it is important to note that there is a technical distinction between a "chimera" and a "hybrid," most legal and ethical discussions use these terms interchangeably. An embryonic a-h chimera results from grafting stem cells_-pluripotent cells that have the capability of developing into specialized cells and tissues - from one species into an embryo of another species, or, in the case of a hybrid, by implanting the nucleus of a human somatic cell into an enucleated animal ovum.

There are several potential uses of a-h chimeras and hybrids that may justify their creation (Prabhune 2000; NRC/IOM 2005). First, a full-term a-h chimera-one that is implanted and allowed to develop beyond the embryonic and fetal stages — could serve as a source of transplantable organs. Esmail Zanjani has created full-term human-to-sheep chimeras with the hope of creating a human liver. Between seven and fifteen percent all the cells in the sheep's livers were human and a few human liver cells formed clusters, giving functionally and fully human liver units available for transplantation as auxiliary organs (Westphal 2003). Second, full-term a-h chimeras could be used as novel research models with the potential to offer great insight into the study of cellular maturation and migration, as well as oncogenesis. The SCID-hu mouse is one historical example in which a mouse had been altered to develop a complete human immune system in order to conduct HIV

\footnotetext{
${ }^{3}$ This section is derived from Ballard 2008.
} 
research (Kaneshima et al. 1990). A more recent study that has received a great deal of attention is the human-mouse neural chimera created by Irving Weissman. The transplantation of human embryonic stem cells [hESCs] into the developing mouse brain could provide a valuable model to study the differentiation and migration of hESCs for regenerative medicine and drug discovery (Muotri et al. 2005). Transplanted human neural stem cells were grafted into mouse fetuses, creating chimeric mice whose brains are about 1\% human (Weiss 2004). By dissecting the mice at various developmental stages, Weissman's experiments have provided insight as to how the added human neural cells move about as they multiply and make connections with the mouse cells. The next step is to transplant human neural stem cells with defects that cause Parkinson's disease, Lou Gehrig's disease, and other brain ailments to study how these cells make neural connections with the hope of creating cell replacement strategies in the adult human brain as a cure (Brüstle 1999). Third, a-h hybrids may serve as an alternative source for hESCs. Because the harvesting of hESCs from a hybrid embryo may not involve the destruction of a human embryo, but rather that of an animal embryo which contains hESCs, the ethical quandaries surrounding the use of human embryos to derive hESCs would be circumvented. $^{4}$

\section{Ontological CAtegorization And Moral Status Animal-Human Chimeras ${ }^{5}$}

In order to establish the ontological status of a-h chimeras, ${ }^{6}$ it is first necessary to outline a metaphysical framework in which relevant ontological categories are

\footnotetext{
${ }^{4}$ Early trials aimed at this third purpose have not produced promising results (Chung et al. 2009). However, initial negative results should not be taken as conclusive until further studies either confirm their findings or fail to circumvent the problems encountered. Consider, for example, that it took 277 attempts to create the famed sheep "Dolly" in 1997 (Wilmut et al. 1997, Table 1). Furthermore, even if a-h hybrids ultimately prove to be useless for this purpose, there remain other purposes specified above for which a-h chimeras may be created and utilized in research.

${ }^{5}$ This section includes material derived from Eberl 2005.
} 
distinguished. Following distinctions first drawn by Aristotle and later augmented by Thomas Aquinas, we propose the following ontological categories and note what specific types of beings may occupy each one: (a) absolutely perfect being, e.g. God; (b) immaterial rational being, e.g. what Christians call "angels"; (c) rational animal, e.g. human beings; (d) non-rational sentient animal, e.g. dogs and snails; (e) non-sentient living organism, e.g. plants and cells; (f) non-living substance, e.g. wood and stone (Aquinas 1948, Ia, Q. 47, a. 2; Aristotle 1984, 413a21-415a14; Code and Moravcsik 1992). These categories are neither the broadest nor narrowest that may be defined. For example, (a) and (b) may be grouped under the larger category of "immaterial being," while (c), (d), (e), and (f) may be grouped under the larger category of "material being"; and Aquinas subdivides (b) into numerous species of angels distinguished by their respective levels of intelligence (Aquinas 1948, Ia, Q. 50, a. 4).

Nevertheless, these categories_-particularly (c)-(f) — are the most relevant to the current discussion of a-h chimeras. They are determined by Aquinas both a priori, based on his reasoning of what sort of natural order would best reflect God's nature in creation (Aquinas 1975, Bk. II, chs. 39-45; Kretzmann 1998, ch. 6), and a posteriori based on what he and Aristotle observed to be the various types of beings in the world. So determined, it need not be the case that there exist any members for a given category. For example, the universe may have been such that there were no non-rational sentient animals; nonetheless, the category would exist with the possibility of having one or more members. In addition, God is traditionally considered to be the one and only member of (a); but this category

\footnotetext{
${ }^{6}$ Except where differentiation is warranted, we will use the term "a-h chimera" to refer to both chimeras and hybrids.
} 
may be defined while leaving open the question of whether God exists and, if so, is the one and only member of it. ${ }^{7}$

Human beings have been typically understood to be the one and only members of (c): rational animal. This leads to the bias Jason Scott Robert and Robert Baylis note that human beings occupy "a privileged place between the angels and all nonhuman animals" (Robert and Baylis 2003, 9). ${ }^{8}$ But the ontological category "rational animal" does not necessarily correspond exclusively with the biological category "homo sapiens"; nor is it the case that any "privileged" status human beings enjoy is due merely to our ontological ranking (Pasnau 2002, 396-402). Biological species categories are subsets of the ontological categories (c)-(e); for example, although dogs and cats are not members of the same biological category, they are members of the same ontological category: non-rational sentient animal. And while it is generally believed that human beings are the only rational animals in the world, continued study of dolphins, chimpanzees, gorillas, and other animals which exhibit highly developed cognitive skills may cause us to expand the membership of this ontological category to include those biological species (DeGrazia 2007). ${ }^{9}$

\footnotetext{
${ }^{7}$ Aquinas, of course, argues that this category is both non-empty (Aquinas 1948, Ia, Q. 2, a. 3) and can have only one member (Aquinas 1948, Ia, Q. 11, a. 3).

${ }^{8}$ This bias was first expressed in the $7^{\text {th }}$ or $8^{\text {th }}$ century B.C. by the writer of Psalm 8, v. 4-9, in the Hebrew Bible: “4 When I see your heavens, the work of your fingers, the moon and stars that you set in place- ${ }^{5}$ What are humans that you are mindful of them, mere mortals that you care for them? ${ }^{6}$ Yet you have made them little less than a god, crowned them with glory and honor. ${ }^{7}$ You have given them rule over the works of your hands, put all things at their feet: ${ }^{8}$ All sheep and oxen, even the beasts of the field, ${ }^{9}$ The birds of the air, the fish of the sea, and whatever swims the paths of the seas" (New American Bible).

${ }^{9}$ If certain species of non-human animals prove to meet the criteria for membership in the ontological category rational animal, they will still biologically differ from each other and the human species in various ways - e.g., in addition to rational animal, Aristotle characterizes the human species as "featherless biped" (Aristotle 1984, 1037b8-1038a35) — which, having progressed far beyond Aristotle in biological science, can be defined by reference to genotypic and not only phenotypic qualities. As David DeGrazia contends, however, such differences would not be morally relevant. Although, there would still be relevant significant differences among the cognitive capacities of human beings and other species of animals, even if the latter qualify as rational, such that only humans would enjoy the full panoply of moral and legal rights - such as the
} 
We next need to explore the relationship between being human, or being a rational animal, and being a person; for the latter category has been historically understood to refer to beings who possess an ontological and ethical significance beyond other types of beings. Does being human, or a rational animal, entail that one is also a person? The earliest philosophical definition of personhood comes from Boethius, who defines a person as an "individual substance of a rational nature" (Boethius 1918, 85). This definition predominated for over a millennium and allowed Christian scholars to define various types of non-human persons, such as the three persons of the Godhead (Aquinas 1948, Ia, QQ. 29-30). John Locke offers an alternative definition of a person as "a thinking intelligent Being, that has reason and reflection, and can consider itself as itself, the same thinking thing in different times and places" (Locke 1975, Bk. II, ch. 27, §9). This definition also allows for the possibility of myriad species of non-human persons, as Locke acknowledges (Locke 1975, Bk. III, ch. 11, §16). Contemporary philosophers have perpetuated the thesis that a person is any being that exhibits the capacity for self-conscious rational thought, augmented perhaps by other capacities such as using language to communicate, having non-momentary self-interests, and possessing moral agency or autonomy (Singer 1992, 84; Warren 1994, 308; Tooley 1983, 146).

These three ways of defining personhood are not inherently contrary to each other, since they all include the criteria of either rationality or self-consciousness, such that any being who possesses the capacity for both would undoubtedly qualify as a person. ${ }^{10}$ There are significant differences, however, in terms of what each specific definition may imply.

right to participation in a democratic society — while the most fundamental of moral rights and consequent legal protections - such as the right not to be used in research that is likely to harm one and is solely for the benefit of others - would arguably apply to all rational animals, whether human or not (DeGrazia 2007, 314).

${ }^{10}$ Aquinas implicitly augments the Boethian definition to include self-consciousness when he refers to a human rational soul having the capacity to "turn upon" and "know itself" (Aquinas 1996, prop. 15). 
For example, Locke's definition allows for there to be multiple personae co-existing within the same body (Locke 1975, Bk. II, ch. 27, §23); whereas the Boethian definition would preclude such an occurrence due to its requirement that a person be an "individual substance." Furthermore, contemporary theorists vary on the definition of "capacity." Having a capacity for self-conscious rational thought may require either the genetic disposition to develop a brain capable of this level of thought (as we argue below), the actual formation of such a brain late in fetal development, or the actual ability to engage such thought that is not first exhibited until some time after birth (as argued by Peter Singer, Mary Ann Warren, and Michael Tooley). In this paper, we will follow Aquinas in adopting the Boethian definition of personhood due to both its perennial influence and its inclusive scope as to what types of beings may count as persons-sufficiently wide to include various non-human beings, while disallowing the counterintuitive implications of the Lockean definition. In further specifying the "rational nature" portion of the Boethian definition, we will argue for a conception of the capacity for self-conscious rational thought contrary to the view promoted by Singer, Warren, and Tooley.

Having adopted Boethius's definition of personhood, Aquinas contends that every human being is, by definition, a person (Aquinas 1948, Ia, Q. 29, a. 1; IIIa, Q. 16, a. 12 ad 1; Eberl 2004); although, as we will discuss below, not every member of the biological species homo sapiens is a "human being." A human being possesses all the relevant capacities for the definitive mental activities of persons at every stage of her existence. At the embryonic stage, these capacities are present because the embryo has the complete human genome and other intrinsic biological factors that are sufficient — if provided a 
supportive environment - for it to develop on its own into an actually self-conscious rational being.

Aquinas distinguishes between an "active potentiality" to perform some operation and the actual operation that is brought about through some additional cause (Aquinas 1948, Ia, Q. 48, a. 5; Q. 76, a. 4 ad 1; 1952a, Q. 1. a. 1; 1952b, Q. 5, a. 8 ad 10; 1999, Bk. II, lect. 2). In contrast to an active potentiality, something has a "passive potentiality" if it can be the subject of externally directed change such that it can become what it is not already. Active potentiality comes in two varieties. The first is what Robert Pasnau refers to as a "capacity in hand" to perform an operation, which means that no further development or significant change is required for the potentiality to be actualized (Pasnau $2002,115)$. For example, a person may have, as an active potentiality, the capacity to speak Spanish if, for example, they had majored in it in college. But it may happen to be the case at any one moment a person with this active potentiality may not be using this capacity and so it is not in actual operation, which it would be if that person were actually speaking Spanish at that moment. The second is what Norman Kretzmann refers to as a substance's "natural potentiality" to develop a capacity to perform an operation (Kretzmann, 1999, 39). For example, before having learned Spanish and thus developed a capacity to do so, a person would have a natural potentiality to develop this capacity, just as one might have numerous other natural potentialities, some of which may be developed into capacities in hand while others are left undeveloped.

In applying these concepts, Aquinas contends that all that is required for something to be a rational animal is for it to have an active potentiality to perform rational operations. The actual performance of such operations is accidental to a rational animal's existence 
(Aquinas 1948, Ia, Q. 118, a. 1 ad 4; 1984, a. 12; Kretzmann 1999, 379 n. 27). A developing human being - even while still in utero - has an active potentiality for rational thought; although it cannot yet actually think rationally. By contrast, sperm and ova do not have such an active potentiality. Rather, a sperm cell or ovum is best understood as having a passive potentiality to become a living, sensitive, and rational human being (Aquinas 1995, Bk. IX, lect. 6, §1837). Each must undergo a change brought about by an extrinsic principle: sperm must be changed through union with an ovum and vice versa, which transforms them into a substance with active potentialities for a rational animal's definitive operations. Once this "substantial change" occurs, a rational animal exists even if it is not actually exercising all of its definitive operations.

The change required for something to actualize an active or passive potentiality is brought about by its "proper active principle." An active principle is required because a potentiality can be actualized only by something that is already in a state of actuality. Something can be moved from a state of potentiality to a state of actuality only by some active principle that is either internal or external to it. A sufficient condition for something's having an active potentiality is if it can actualize the potentiality by some active principle internal to it. From the moment the fertilization process is complete, a human embryo has a complete human genome and other material factors that are sufficient — given a supportive environment—for it to develop a functioning cerebral cortex supportive of rational thought. From this fact, one can infer that a human embryo, well before it forms a functioning cerebral cortex, has an active potentiality for rational thought insofar as it has a natural potentiality to develop a capacity in hand for such operations. 
The relevant question, with respect to the creation of an a-h chimeric embryo, is whether the grafting of human cells into an animal embryo, or vice versa, would be sufficient to result in a substantial change-one kind of being becomes another kind of being, and hence the same being does not persist through this change — or an accidental change - the same being adds or subtracts certain non-essential traits, but remains the same kind of being. For example, although a woman's hair may change color as she grows older or she may lose a limb, she remains the same person through these accidental changes. On the other hand, burning a wooden desk substantially changes it from a wooden structure into something entirely different: a pile of ashes. The latter change is not identitypreserving. The Thomistic view, by conceptualizing a human embryo as a person from the beginning, holds that an embryo undergoes a series of accidental changes as it proceeds from being an embryo to a fetus to a newborn baby and so on; but its substantial nature as a rational animal remains the same throughout these developmental stages. Thus, a human embryo is a person from the outset, despite the fact that it must go through a series of accidental changes before it can exhibit the defining feature of personhood: self-conscious rational thought.

Hence, an a-h chimeric embryo is not a person simply by virtue of being constituted by some cells with human DNA. In fact, even a biological entity constituted by all and only cells with human DNA is not necessarily a human person - e.g. a hydatidiform mole. ${ }^{11}$ Nor have they been historically viewed as such. For example, a SCID-hu mouse, despite having a complete human immune system, is still treated as a mouse (Greely et al.

\footnotetext{
${ }^{11}$ A hydatidiform mole is a mass of placental tissue with the same genetic identity as a human embryo. What distinguishes a hydatidiform mole from a developing human embryo is that the former can never develop into an organism with a functioning cerebral cortex, despite its intrinsic genetic structure and even if it is placed in a supportive uterine environment; the latter can. The same is true of some genetically defective embryos.
} 
RUNNING HEAD: Creating Animal-Human Chimeras

2007). The ontological question at hand, on the Thomistic view, is whether an a-h chimeric embryo, through the addition of human cells, possesses the intrinsic capacity—if allowed to develop in a supportive environment - to produce a cerebral cortex that supports selfconscious rational thought.

If an a-h chimeric embryo does possess the relevant capacity for personhood according to Aquinas, what is its moral status? Aquinas holds that a person's intrinsic moral status is based on their nature as a living, sentient, and rational entity. The term "nature" refers to a person's having the intrinsic capacities-i.e., active potentialities_for the activities associated with life, sentience, and rational thought. Rationality, on Aquinas's view, is the highest capacity found among natural substances because it enables a person to come to know universal conceptual truths and to determine their own actions (Aquinas 1948, Ia, Q. 29, a. 1). He thus asserts that personhood is attributed to rational beings insofar as they have a special dignity - i.e., a particular high degree of intrinsic value among other types of beings in nature (Aquinas 1948, Ia, Q. 29, a. 3 ad 2). As noted above, on the Thomistic view, a human embryo is a person from conception due to its inherent capacity to think in a self-conscious rational manner given time for its natural development. Hence, it is a rational animal once the fertilization process is completed and thereby has an intrinsic value that must be promoted. In other words, both negative and positive obligations apply such that it ought to be treated both nonmaleficently and beneficently.

Life, Aquinas contends, is a fundamental good for human persons (Aquinas 1948, Ia-IIae, Q. 94, a. 2; Finnis 1980, 86-87). Without life, none of a person's other inherently valuable capacities_-including self-consciousness and rationality — can occur in the service of contributing to the overall goodness of the natural world in which persons exist and 
flourish. To act against the existence and flourishing of a person constitutes a morally impermissible act — or at least an act that requires stringent justification — that ought to be avoided if at all possible. Therefore, if certain types of a-h chimeras qualify as persons, then any experiments that involve their destruction, or otherwise harm them when it is not to their own benefit, would be impermissible — or at least require stringent justificationdespite whatever other goods may be promoted through such experimentation.

It is important to differentiate the Thomistic view from what Robert Streiffer terms the "anthropocentric view," which holds that "normal adult human beings have the moral status they do simply because they are human beings, that is, because they are members of the species homo sapiens" (Streiffer 2005, 356). Although Aquinas explicitly holds that all human beings are persons, and thus enjoy the moral status that ought to be ascribed to persons, it is not necessarily the case that all members of the biological species homo sapiens are "human beings" as Aquinas defines the term. For Aquinas, in order to be a human being, one must be a rational animal. It may be the case, however, that some entities that are biologically "human" are nonetheless not rational animals. A relevant example may be some anencephalic infants whose anencephaly results from a genetic defect present from conception which precludes their possessing the intrinsic capacity to develop a cerebral cortex supportive of self-conscious rational thought. According to Streiffer, "an anencephalic infant is a human being and would possess human moral status on an anthropocentric view" (Streiffer 2005, 357). On the Thomistic view, however, an anencephalic infant that does not possess an intrinsic capacity for self-conscious rational 
thought would not be a human being — or a person — insofar as it is not a rational animal, despite its membership in the biological species homo sapiens. ${ }^{12}$

\section{Predicting Whether AN A-H Chimera Is A "Person"13}

To be held in the moral regard we currently grant to persons, an a-h chimera first has to be definable ontologically as such. If an animal embryo having human cells grafted into it becomes capable of developing self-conscious rational thought, then a substantial change has occurred insofar as the embryo has moved from being a non-rational sentient animal to being a rational animal. If, however, the grafting of human cells were insufficient for the embryo to become capable of developing self-conscious rational thought, then its acquisition of any other "human" traits would constitute a change that leaves the embryo firmly in the ontological category of non-rational sentient animal. Such a change could be accidental in that the embryo would remain only a non-rational animal; however, the change could be substantial within this category insofar as a new species of animal is created, one which is to some degree "human" but not a person. Aquinas acknowledges the creation of such new species within the order of nature; he refers to mules, for example, as an "intermediate species" engendered from the species of horse and ass (Aquinas 1948, Ia, Q. 73, a. 1 ad 3; Adler 1940).

The Thomistic view would grant an a-h chimera the moral status of a person if it has the capacity for self-conscious rational thought, since it is member of the ontological category of rational animal. But scientific questions persist as to the likelihood of

\footnotetext{
${ }^{12}$ Note that this conclusion applies only to anencephalic infants whose anencephaly results from a genetic defect such that they never possess an active potentiality for self-conscious rational thought. Anencephaly may also result from environmental causes during the course of pregnancy such that the infant's active potentiality for self-conscious rational thought becomes inhibited; such anencephalic infants, by virtue of being rationally ensouled at conception, would qualify as human beings despite later becoming unable to develop a brain supportive of self-conscious rational thought.

13 This section includes material derived from Ballard 2008.
} 
conferring such a capacity through the grafting on human cells into a nonhuman embryo. Four factors have been offered as predictors: (1) quantity of human material transferred; (2) timing of the grafting; (3) what type of cells are grafted; and (4) what host animal is utilized (Karpowicz, Cohen, and van der Kooy 2004, 125; NRC/IOM 2005, 40-41; Greene et al. 2005, 386). Quantity has been viewed as an important indicator because if human cells greatly outnumber host cells in an early embryo, particularly in a developmentally similar host, it is conceivable that human-like psychological capacities might emerge in the resulting a-h chimera. Timing is also considered an important factor because of "the potential for engrafted cells to have significant functional influence will be markedly greater for engraftment at very early stages of development than for engraftment into the established architecture of adult brains" (Greene et al. 2005, 386). Furthermore, the distinction between grafting neural and non-neural cells is considered significant, particularly in combination with a high quantity of cells engrafted at an early stage of development.

A dramatic experiment utilizing a chick-quail chimera offers some evidence that the transfer of complex behaviors may indeed be possible. Evan Balaban and colleagues took small sections of the brain of a developing quail and transplanted them into the developing brains of chickens (Balaban, Teillet, and Le Dourain 1988). The result was chickens that exhibited the vocal trills and head bobs unique to a quail, thereby providing proof that the chimera's brain contained the neural circuitry for quail calls. While this experiment did not transfer human behaviors or the capacity for rational thought across species lines, it nevertheless provides early evidence that complex behaviors could be transferred across species. 
Although the quail-chick chimera indicates that it is possible to transfer complex behaviors, it is still largely unknown whether the addition of human genes or human hESCs into an animal embryo will lead to the development of the capacity for selfconscious rational thought (NRC/IOM 2005, 41; Karpowicz, Cohen, and van der Kooy 2005, 124-126). There is evidence, however, that human neural stem cells do contribute to the developing brain of primates. Various experiments have shown that injected human neural stem cells will distribute throughout a developing monkey's brain, including the frontal areas supportive of higher-level thinking, and actively participate in neural functioning (Ourednik et al. 2001).

Ethicists have given the green light for experiments such as Weissman's, described above, in which human neural cells are added to mice; but there is hesitation with respect to neural stem cell experiments involving primates: "If the recipient blastocyst were from an animal that is evolutionarily closer to a human, the potential for human contributions would appear to be greater ... The need for the use of blastocysts from larger mammals [than mice] would need to be very clearly justified and nonhuman primate blastocysts should not be used at this time" (NRC/IOM 2005, 41).

David DeGrazia goes further in arguing that members of certain nonhuman primate species, the Great Apes, already qualify as at least "borderline persons" — as is also the case, he argues, with human children who are unable to understand language — and thereby "have moral status equal to our own” (DeGrazia 2007, 322-323). DeGrazia’s contention that the Great Apes, by their own nature before any human DNA is introduced, may qualify — to use Thomistic terminology — as rational animals is well-taken. It coheres with the general Thomistic thesis that the ontological category of rational animal may be 
extended to members of other biological species than just homo sapiens. ${ }^{14}$ In fact, although Aquinas does not explicitly grant nonhuman animals intrinsic moral status, his overall ethical view leads to the conclusion that nonhuman animals have a certain degree of intrinsic moral status - albeit less than that of human beings - due to their ontological categorization as at least sentient beings (Barad 1988). If any nonhuman animals are not only sentient, but also rational—as DeGrazia contends — then their intrinsic moral status may indeed be equivalent to that of human beings.

\section{Moral Permissibility of Creating AND ExPERIMENTING UpON A-H CHIMERAS}

It is difficult to demonstrate the ultimate influence of the four predictive factors described above but to create a-h chimeras and observe their mental capacities (Streiffer 2005, 355-356). Additionally, "even if we observe what appear to be more humanlike capacities in an engrafted animal, we may be unable to establish whether the capacities are outside of the normal range for that species, or to interpret the moral meaning of observed changes" (Greene et al. 2005, 385). Thus, the task remains of drawing a line in the sand as to what is and is not morally permissible - recognizing and working within our limited scientific knowledge. Applying the Thomistic view, however, can help to draw some moral conclusions. Our moral premise based on this view is that if an a-h chimera has the intrinsic capacity to develop self-conscious rational thought, it is a rational animal and thereby possesses the same moral accord as a human person; research on such a chimera would thus be akin to conducting research on a human being and it should be protected under the ethical standards protective of human research subjects.

\footnotetext{
${ }^{14}$ Personhood would also be extended to such animals insofar as Aquinas applies this label to all rational beings.
} 
As for deciding which types of chimeras are likely to develop rational thought, we concur with the four factors of quantity, timing, type of cells grafted, and host animal as important predictive indicators. Based on these factors, we agree with the NRC/IOM's prediction that the a-h chimera types most likely to develop the capacity for self-conscious rational thought are neural chimeras and human-nonhuman primate chimeras. Creating a human-nonhuman primate chimera using neural hESCs involves a significantly high degree of probability of producing a substantial change in which an embryo moves from being a non-rational sentient animal to being a rational animal. Given such probability, the moral justification for creating such an entity in the first place would have to be extremely strong, and probably no justification is sufficiently strong to justify the creation of these kinds of chimeras. Furthermore, if such chimeric embryos were created, the moral permissibility of research performed on them should be determined by a rigid moral standard equivalent to that used to judge the moral permissibility of experiments involving human embryos as research subjects.

The creation of all other chimeras not involving neural hESCs or primates either results in an accidental change in the animal, in which the addition of non-essential elements — such as human immune system cells or human skin cells_yields a chimera that remains a non-rational sentient animal. ${ }^{15}$ We may thus treat a-h chimeras with no rational capacity as we would other evidently non-rational sentient animals. A relevant moral question remains, however, concerning whether the risk of crossing the line between an animal with human cells to an a-h chimera that is rational is justified based on the benefit to be gained from creating such entities — we address this question below.

\footnotetext{
${ }^{15}$ The resulting change may be substantial if the a-h chimera is of a distinct biological species from the original animal embryo - akin to the creation of a mule - but the new substantial entity would still be a member of a biological species that belongs to ontological category of non-rational sentient animal.
} 
In analyzing the uses of a-h chimeras, we draw a distinction between those uses that require full-term chimeras and those that require only the creation of embryos, which are destroyed in the realization of the research goals. Uses that require a chimera to be brought to full-term include being an alternative model for testing drug efficacy, an organ source, or a basic research tool-depending on the research protocol. Some research protocols require only an embryo, such as using embryonic chimeras to study the characteristics of hESCs; and using embryonic hybrids as an alternative source for hESCs requires only the creation of an embryo which is destroyed - typically prior to the $14^{\text {th }}$ day in culture-in order to derive stem cells.

On the Thomistic evaluation of such uses, an a-h chimeric embryo of the type that would likely possess the capacity for self-conscious rational thought would thus likely be a person. Since a human embryo is considered to begin life as a rational animal, according to the Thomistic view, then any experimentation that would harm or destroy a human embryo or an a-h chimera of the relevant type is morally problematic or outright impermissible. ${ }^{16}$ However, when there is no intrinsic capacity for self-conscious rational thought, the chimera is not considered a person despite its containing human DNA. Therefore, if we can exclude the possibility of dealing with a chimera that is a rational animal, the Thomistic view may support creating and experimenting upon a-h chimeras - both fullterm and embryonic.

Even when dealing with an entity that is non-rational, however, the question remains whether an a-h chimera should be afforded extra protection than its animal

\footnotetext{
${ }^{16}$ Although it is generally presumed that one may not intentionally harm or kill a person, there are certain exceptions that various people argue for-e.g., capital punishment, killing in a just war, or euthanasia. While the metaphysical conclusion of what counts as a person is a necessary first step to resolving these and other moral issues, the additional lens of a particular moral theory is also required to develop complete responses to these dilemmas (Kavanaugh 2001; McMahan 2002; Eberl 2006).
} 
counterparts based upon the risk that it may possess the capacity for self-conscious rational thought. Affording higher moral status to animals because of their close mental capacity with that of humans is practiced despite the fact that such animals are generally considered non-rational; chimps and apes are afforded more special treatment than other laboratory research animals. Is it thus morally justifiable to risk the creation of an a-h chimera, for the purpose of beneficial research in which the chimera will be harmed or destroyed, which may have a capacity for self-conscious rational thought?

Thomistic moral theory recognizes the validity of the Principle of Double-Effect [PDE] (Eberl 2003). PDE states that an action taken to produce some consequence, that is good per se, may be permissible even if the action produces a foreseen negative consequence that is bad per se. This principle holds provided that the relative value of the negative consequence does not outweigh that of the good consequence, the negative consequence is not directly intended as an end or the means by which the good consequence is brought about, and the act itself is not morally impermissible. Denis Sullivan and Thomas Cavanaugh, in interpreting Aquinas's original formulation of PDE, both add that one is justified only in risking a foreseen negative consequence (Aquinas 1948, IIa-IIae, Q. 64, a. 7; Cavanaugh 1997, 116-119; Sullivan 2000, 437).

Ethicists who object to abortion and the use of abortifacient contraceptives have appealed to PDE, thus understood, to address the case of using an emergency contraceptive pill $[\mathrm{ECP}]$ after rape. ${ }^{17}$ An ECP may function as an abortifacient by preventing an embryo's implantation in the uterus; however, it may also function as simply a contraceptive by preventing ovulation or fertilization, or not function at all given the uncertainty that a rape victim was in her fertile period at the time of the attack. Norman

\footnotetext{
${ }^{17}$ This paragraph is derived from Eberl 2006.
} 
Ford analyzes statistical data regarding the frequency of pregnancies after rape and the various potential causes of some of those pregnancies failing naturally, as opposed to being caused by ECPs. He concludes, "Conservatively, one could assume that the risk to the life of an embryo [by utilizing an ECP after rape] would be about 8 percent or less" (Ford 2002, 94). In the absence of confirmatory evidence that fertilization has occurred in a woman who has been raped, the risk that using an ECP would cause an embryo to abort is sufficiently low to justify its use in the case of rape by appeal to PDE (Ford 2002, 94-95). Although one may directly intend to abort an embryo by using an ECP, the low probability that an embryo may be present to be aborted also allows one to directly intend only the prevention of ovulation or fertilization, which is a morally acceptable good worth pursuing in comparison to the overwhelming emotional hardship — along with other potential burdens - a rape victim who finds herself pregnant may face.

We contend that the ethical justification of risking the creation and use in potentially beneficial research of an a-h chimera that has an inherent capacity for selfconscious rational thought is analogous to the justified risk that an ECP may function as an abortifacient. Provided that the risk of having created an a-h chimera that qualifies as a person is sufficiently low-which can be judged based on the predictive factors described above and thus avoiding, for example, the grafting of neural hESCs into primate embryos - then research that involves the creation and use of other types of a-h chimeras could go forward so long as the therapeutic research goals are proportionate to the relatively low risk that a person may be created, and subsequently harmed or killed, by the research. 


\section{CONCLUSION}

Regarding the, at present hypothetical, case of an a-h chimera that has a sufficiently "human" genetic endowment to develop a cerebral cortex supportive of self-conscious rational thought, our ethical conclusion echoes that of Philip Karpowicz and colleagues: "If such a chimera exhibited signs of emergent human mental capacities, conducting biomedical experiments upon it might be essentially equivalent to conducting the same experiments on a human person. Human dignity would be undermined by the transfer of emergent and super cellular psychological human functions into research subjects that consequently possess the same capacities themselves. This argument presents the most compelling reasons to prohibit chimera experiments so far" (Karpowicz, Cohen, and van der Kooy 2004, 333-334). In most other cases involving the creation of a-h chimeras, however, which avoid grafting neural hESCs into primate embryos, the risk that a rational animal — a person — would be created is sufficiently low to allow the research to proceed under the ethical limitations appropriate to research with nonhuman animals. ${ }^{18}$

\section{REFERENCES}

Adler, Mortimer J. 1940. Problems for Thomists: The problem of species. New York: Sheed \& Ward.

Aquinas, Thomas. 1948. Summa theologiae, trans. Fathers of the English Dominican Province, 5 vols. New York: Benziger.

-----. 1952a. De potentia Dei, trans. Fathers of the English Dominican Province, 3 vols. Westminster: Newman Press.

\footnotetext{
${ }^{18}$ The metaphysical and ethical conclusions for which we argue in this paper would also be applicable to cases in which animal cells were grafted into human embryos. The "humanness" of such embryos would not be diminished if such grafting did not negatively interfere with the development of the embryos' intrinsic capacity for self-conscious rational thought. This claim does not imply, however, that it would be permissible to perform such research insofar as whatever changes that were to accrue to the embryo are not ones that the embryo could autonomously choose for itself. But if the changes were to endow the embryo with a significant improvement, such as an enhanced immune system, that any rational being would choose for itself, then there is a window for possible justification of such enhancements. This discussion, however, takes us well outside the scope of this paper.
} 
RUNNING HEAD: Creating Animal-Human Chimeras

-----. 1952b. Quaestiones disputatae de veritate, R. Mulligan, J. McGlynn, and R. Schmidt, 3 vols. Chicago: Henry Regnery.

----. 1975. Summa contra Gentiles, trans. Anton Pegis, James F. Anderson, Vernon Bourke, and Charles J. O’Neil, 5 vols. Notre Dame: University of Notre Dame Press.

-----. 1984. Quaestio disputata de anima, trans. James H. Robb. Milwaukee: Marquette University Press.

----- 1995. Sententia super Metaphysicam, trans. John P. Rowan. Notre Dame: Dumb Ox Books.

----. 1996. Super librum de causis expositio, trans. Vincent A. Guagliardo, Charles R. Hess, and Richard C. Taylor. Washington, DC: Catholic University of America Press.

-----. 1999. Sententia libri De anima, trans. Robert Pasnau. New Haven: Yale University Press.

Aristotle. 1984. Metaphysics, On the soul, History of animals, Parts of animals, Generation of animals, On plants, ed. Jonathan Barnes. The complete works of Aristotle, 2 vols. Princeton: Princeton University Press.

Balaban, Evan, Marie-Aimee Teillet, and Nicole Le Dourain. 1988. Application of the quail-chick chimera system to the study of brain development and behavior. Science 241: 1339-1342.

Ballard, Rebecca A. 2008. Animal/Human Hybrids and Chimeras: What are They? Why Would Scientists Create Them? And What Attempts Have Been Made to Regulate Them? Michigan State University Journal of Medicine and Law 12: 297-319.

Barad, Judith. 1988. Aquinas's inconsistency on the nature and the treatment of animals. Between the Species 4: 102-111.

Brüstle, Oliver. 1999. Building brains: Neural chimeras in the study of nervous system development and repair. Brain Pathology 9: 527-545.

Cavanaugh, Thomas A. 1997. Aquinas's account of double effect. The Thomist 61: 107-112.

Chung, Young, Colin E. Bishop, Nathan R. Treff, Stephen J. Walker, Vladislav M. Sandler, Sandy Becker, Irina Klimanskaya, Wan-Song Wun, Randall Dunn, Rebecca M. Hall, Jing Su, Shi-Jiang Lu, Marc Maserati, Young-Ho Choi, Richard Scott, Anthony Atala, Ralph Dittman, and Robert Lanza. 2009. Reprogramming of human somatic cells using human and animal oocytes. Cloning and Stem Cells 11: 1-11. 
Code, Alan, and Julius Moravcsik. 1992. Explaining various forms of living, eds. Martha C. Nussbaum and Amelie O. Rorty. Essays on Aristotle's De anima. (pp. 129-145) Oxford: Clarendon Press.

DeGrazia, David. 2007. Human-animal chimeras: Human dignity, moral status, and species prejudice. Metaphilosophy 38: 309-329.

Donnelly, Matt. May 23, 2005. The peril and promise of mix-and-match biotech: Is a proliferation of human-animal mixtures good for either? Science \& Theology News, http://www.stnews.org/print.php?article_id=533 (accessed June 19, 2006).

Eberl, Jason T. 2006. Thomistic principles and bioethics. New York: Routledge.

-----. 2005. Aquinas's account of human embryogenesis and recent interpretations. Journal of Medicine and Philosophy 30: 379-394.

-----. 2004. Aquinas on the nature of human beings. Review of Metaphysics 58: 333-365.

-----. 2003. Aquinas on euthanasia, suffering, and palliative care. The National Catholic Bioethics Quarterly 3: 331-354.

Finnis, John. 1980. Natural law and natural rights. Oxford: Clarendon Press.

Ford, Norman. 2002. The prenatal person: Ethics from conception to birth. Oxford: Blackwell.

Franklin, Sarah. 2003. Drawing the line at not-fully human: What we already know. American Journal of Bioethics 3: 25-27.

Greely, Henry T., Mildred K. Cho, Linda F. Hogle, and Debra M. Satz. 2007. Thinking about the human neuron mouse. American Journal of Bioethics (AJOB-Neuroscience) 7: $27-40$.

Greene, Mark, Kathryn Schill, Shoji Takahashi, Alison Bateman-House, Tom Beauchamp, Hilary Bok, Dorthy Cheney, Joseph Coyle, Terrence Deacon, Daniel Dennett, Peter Donovan, Owen Flanagan, Steven Goldman, Henry Greely, Lee Martin, Earl Miller, Dawn Mueller, Andrew Siegel, Davor Solter, and John Gearhart. 2005. Moral issues of human—non-human primate neural grafting. Science 309: 385-386.

Kaneshima, H., C. Baum, B. Chen, R. Namikawa, H. Outzen, L. Rabin, A. Tsukamoto, and J. M. McCune. 1990. Today's SCID-hu mouse. Nature 348: 561-562.

Karpowicz, Philip, Cynthia B. Cohen, and Derek van der Kooy. 2004. It is ethical to transplant human stem cells into nonhuman embryos. Nature Medicine 10: 331-335. 
RUNNING HEAD: Creating Animal-Human Chimeras

-----. 2005. Developing human-nonhuman chimeras in human stem cell research: Ethical issues and boundaries. Kennedy Institute of Ethics Journal 15: 107-134.

Kavanaugh, John F. 2001. Who count as persons: Human identity and the ethics of killing. Washington, DC: Georgetown University Press.

Kretzmann, Norman. 1998. The metaphysics of creation: Aquinas 's natural theology in Summa contra Gentiles II. Oxford: Clarendon Press.

McMahan, Jeff. 2002. The ethics of killing: Problems at the margins of life. New York: Oxford University Press.

Muotri, Alysson R., Kinichi Nakashima, Nicolas Toni, Vladisla Sandler, and Fred H. Gage. 2005. Development of functional human embryonic stem cell-derived neurons in mouse brains. Proceedings of the National Academy of Sciences 102: 18644-18648.

National Research Council and Institute of Medicine (NRC/IOM). 2005. Guidelines for human embryonic stem cell research. Washington, DC: The National Academies Press, http://fermat.nap.edu/books/0309096537/html (accessed June 19, 2006).

Ourednik, V., J. Ourednik, J. D. Flax, W. M. Zawada, C. Hutt, C. Yang, K. I. Park, S. U. Kim, R. L. Sidman, C. R. Freed, E. Y. Snyder. 2001. Segregation of human neural stem cells in the developing primate forebrain. Science 293: 1820-1824.

Pasnau, Robert. 2002. Thomas Aquinas on human nature. New York: Cambridge University Press.

Prabhune, Kaustubha A. 2000. Mixed allogenic chimerism and tolerant to composite tissue allografts. Microsurgery 20: 441-447.

Robert, Jason Scott, and Francoise Baylis. 2003. Crossing species boundaries. American Journal of Bioethics 3: 1-13.

Rabin, Sander. 2006. The human use of humanoid beings: Chimeras and patent law. Nature Biotechnology 24: 517-519.

Singer, Peter. 1992. Embryo experimentation and the moral status of the embryo, ed. Eric Matthews and Michael Menlowe. Philosophy and health care (pp. 81-91) Brookfield: Avebury.

Streiffer, Robert. 2005. At the edge of humanity: Human stem cells, chimeras, and moral status. Kennedy Institute of Ethics Journal 15: 347-370.

Sullivan, Denis. 2000. The doctrine of double effect and the domains of moral responsibility. The Thomist 64: 423-448. 
RUNNING HEAD: Creating Animal-Human Chimeras

Tooley, Michael. 1972. Abortion and Infanticide. Philosophy and Public Affairs 2: 37-65.

Warren, Mary Anne. 1994. On the moral and legal status of abortion, ed. Tom L.

Beauchamp and LeRoy Walters. Contemporary issues in bioethics, $4^{\text {th }}$ ed (pp. 302-311). Belmont: Wadsworth.

Weiss, Rick. November 20, 2004. Of mice, men and in-between: Scientists debate blending of human, animal forms. Washington Post: A1, A8.

Westphal, Sylvia Pagán. 2003. Growing human organs on the farm. New Scientist 180: 4-5.

Wilmut, I., A. E. Schnieke, J. McWhir, A. J. Kind, and K. H. S. Campbell. 1997. Viable offspring derived from fetal and adult mammalian cells. Nature 385: 810-813. 